\title{
Preparation of a Zinc Oxide-Reduced Graphene Oxide Nanocomposite for the Determination of Cadmium(II), Lead(II), Copper(II), and Mercury(II) in Water
}

\author{
Wei Liu* \\ School of Architecture, Chang'an University, Xi'an, 710064, P. R. China. \\ *E-mail: cauliuwei@chd.edu.cn
}

doi: $10.20964 / 2017.06 .06$

Received: 26 November 2016 / Accepted: 18 March 2016 / Published: 12 May 2016

\begin{abstract}
An effective electrocatalyst was generated through the hybridization of graphene with ZnO. First, a proper amount of graphene oxide was used to cover the $\mathrm{ZnO}$ nanoparticles. Then, the composite of $\mathrm{ZnO}$ and graphene $(\mathrm{ZnO} / \mathrm{RGO})$ was produced through the in situ reduction of graphene oxide. The obtained $\mathrm{ZnO} / \mathrm{RGO}$ composite was employed to determine $\mathrm{Cu}$ (II), $\mathrm{Cd}(\mathrm{II}), \mathrm{Hg}$ (II) and $\mathrm{Pb}$ (II) in aqueous solutions. The limits of detection for $\mathrm{Cu}$ (II), $\mathrm{Cd}$ (II), $\mathrm{Hg}$ (II) and $\mathrm{Pb}(\mathrm{II})$ were measured to be $0.04 \mu \mathrm{M}$, $0.03 \mu \mathrm{M}, 0.06 \mu \mathrm{M}$ and $0.03 \mu \mathrm{M}$, respectively, which are remarkably lower than the guideline values set by the World Health Organization (WHO).
\end{abstract}

Keywords: Zinc oxide; Graphene; Electrochemical sensor; Mercury; Square wave stripping voltammetry

\section{$\underline{\text { FULL TEXT }}$}

(C) 2017 The Authors. Published by ESG (www.electrochemsci.org). This article is an open access article distributed under the terms and conditions of the Creative Commons Attribution license (http://creativecommons.org/licenses/by/4.0/). 